\title{
Discards of the purse seine fishery targeting small pelagic fish in the eastern Mediterranean Sea
}

\author{
KONSTANTINOS TSAGARAKIS ${ }^{1}$, VASSILIKI VASSILOPOULOU ${ }^{1}$, \\ ARGYRIS KALLIANIOTIS ${ }^{2}$ and ATHANASSIOS MACHIAS ${ }^{1}$ \\ ${ }^{1}$ Hellenic Center for Marine Research, Institute of Marine Biological Resources, Agios Kosmas, 16610, Elliniko, Athens, \\ Greece. E-mail: kontsag@hcmr.gr \\ ${ }^{2}$ Fisheries Research Institute, Nea Peramos, 64007, Kavala, Greece.
}

\begin{abstract}
SUMMARY: We analysed data collected on board commercial purse seine vessels in the Aegean and Ionian Seas (eastern Mediterranean Sea, Greece) in 13 seasonal sampling periods from 2003 to 2008 in order to describe the composition of the retained and discarded catch and shed light on discarding practices. In each area, five species constituted the majority of the marketable catch (>97\%): sardine (Sardina pilchardus), anchovy (Engraulis encrasicolus), round sardinella (Sardinella aurita), bogue (Boops boops) (in both areas), mackerel (Scomber japonicus; in the Aegean Sea) and picarel (Spicara smaris; in the Ionian Sea). Discarded quantities were on average $4.6 \%$ and $2.2 \%$ of the total catch in terms of weight in the Aegean and Ionian Seas respectively. Discards on the marketable ratio fluctuated over years and seasons without showing any particular trend. At the species level, sardine and mackerel were seldom discarded while large amounts of anchovy were discarded only during its recruitment period (autumn), when juvenile fish dominate the population. The discarding ratio for bogue, picarel and round sardinella ranged from zero to total discarding because they constitute a supplementary source of income for the fishers. Discarded fish comprised mainly small individuals for all species considered with the exception of round sardinella. However, the lengths at which $50 \%$ of the individuals were discarded were generally small, often smaller than the species minimum landing sizes. Geographical coordinates and marketable catch explained part of the variability of the discarded quantities, as revealed by generalized additive models. Discarding practices and implications for management of purse seine fisheries are also discussed.
\end{abstract}

Keyworks: purse seine fishery, small pelagic fish, lengths at discarding, commercial species, Aegean Sea, Ionian Sea.

RESUMEN: Descartes de la pesca de cerco enfocadas en peces pequeños pelágicos en el mar Mediterráneo Oriental. - Analizamos datos recogidos a bordo de pesqueros comerciales de cerco en el mar Egeo y el mar Jónico (Mediterráneo Oriental, Grecia) durante 13 estacionales de muestreo desde 2003 hasta 2008, con el objetivo de describir la composición de las capturas conservadas y de las descartadas con el fin de arrojar luz sobre la práctica del descarte. En cada zona, la mayor parte de la captura comercial ( $>97 \%$ ) consistía en cinco especies, a saber: la sardina (Sardina pilchardus), el boquerón (Engraulis encrasicolus), la alacha (Sardinella aurita), la boga (Boops boops) (en ambas zonas), la caballa (Scomber japonicus; en el mar Egeo) y el caramel (Spicara smaris; en el mar Jónico). Las cantidades descartadas representaban un promedio del $4.6 \%$ y $2.2 \%$ de la captura total en términos de peso, en el mar Egeo y en el Jónico respectivamente. La proporción de la captura descartada sobre la captura comercializable fluctuó mucho en todos los años y estaciones sin mostrar ninguna tendencia particular. Con respecto a las especies, en el caso de la sardina y de la caballa, los descartes ocurrieron raramente e incluso los individuos más pequeños se conservaron, mientras que grandes cantidades de boquerón fueron descartadas solamente durante su temporada de reclutamiento (otoño), cuando la población está dominada por peces jóvenes. La proporción descartada en el caso de la boga, del caramel y de la alacha fluctuó mucho, desde un descarte de cero hasta un descarte total, ya que estas especies representan una fuente de ingresos complementaria para los pescadores. Las coordenadas geográficas y la captura comercial explicaban parte de la variabilidad de las cantidades descartadas, como se demuestra con modelos aditivos generalistas. Asimismo, presentamos una discusión sobre la práctica del descarte así como de las consecuencias sobre la gestión de la pesca de cerco.

Palabras clave: pesca de cerco, pequeñas especies pelágicas, longitud al momento del descarte, especies comerciales, mar Egeo, mar Jónico. 


\section{INTRODUCTION}

Estimation of discards, the fraction of the catch that is brought onto the deck and subsequently thrown back into the sea, has been recognized to be crucial for improving stock assessments and exploring the impacts of fishing on the ecosystem (Rochet and Trenkel 2005). The latter has gained attention during the last decade since ecosystem based management (EBM) has been established as a priority in fishery science (Garcia et al. 2003). Discards may directly or indirectly alter food web interactions and the ecosystem structure and functioning (Jennings and Kaiser 1998, Bellido et al. 2011) and constitute an economic and food source waste (Garcia et al. 2003, Bellido et al. 2011). Moreover, stock assessments and fishery management have to take into account discard mortality, which is often significant enough and is an important source of error (Kelleher 2005, Bellido et al. 2011).

Reduction or elimination of discards is one of the core aspects of EBM of fisheries (Hilborn 2011). Several organizations highlight the need to develop new markets for discards and/or increase fishing selectivity (e.g. EU 2009, FAO 2010), although more selective fisheries might decrease community evenness and species richness, contradicting the need to minimize effects on ecosystem structure and function (Rochet et al. 2011). Solving the problem of discards is quite complex, since discards show high variability across time, space and gears due to the numerous factors affecting them, including, among others, market prices, legal measurements such as minimum landing sizes, technical characteristics, environmental conditions, species composition and the size distribution of the community (Rochet and Trenkel 2005). Mitigation measures adopted so far have been proven ineffective, while an integrated approach that will consider legal measurements and their successful application for resource conservation in order to remove or at least reduce incentives to discard might be more appropriate (Gezelius 2008).

The implementation of policies aimed at reducing discards is based on descriptions of the discarded catch and information on the factors that affect discarded quantities and their composition in terms of species and sizes. This information is also critical for future fishery management plans that will need to consider the descriptors of a good environmental status of the EU Marine Strategy Framework Directive (EU 2008). However, discards sampling, which is usually carried out by observers on board commercial vessels, is usually quite expensive (Rochet and Trenkel 2005), and hence discard estimates are often imprecise as a result of limited sampling coverage. Various methods have been developed to estimate discarded quantities based on sample data and assumptions, and the method based on the length frequency distribution of commercial catches is becoming popular (Depestele et al. 2011).
Among the different fishing gears, trawl fishing is responsible for the bulk of discards and consequently little attention has been given to the quantities of discards from other gears, especially purse seines. Existing studies for purse seines indicate that the discard ratio is rather low (Kelleher 2005) because vessels target small pelagic fish with a low diversity of species and sizes. However, the quantity, the composition of the catch and market prices greatly affect the discarded portions, which may be higher at local scale (Santojanni et al. 2005). Moreover, there are documented cases, as in southern Portugal, where mean discard rates per trip for pelagic purse seines reach $27 \%$ (Borges et al. 2001). In any case, given the high quantities of pelagic fish caught by purse seines, at least regionally, even a relatively small ratio may still produce large overall discard quantities and should be taken into account in fishery management.

In Greece, the purse seine fleet is responsible for approximately one third of the total marine catch (El. Stat. 2011) targeting exclusively small pelagic fish, which cannot be caught by bottom or pelagic trawls. The present work aims to describe the discarded catch and discarding practices of the purse seine fishery in two study areas in Greece (east Mediterranean), the north-central western Aegean and the eastern Ionian Seas. Discards data were collected on board commercial vessels and discarded catch was analysed in terms of species composition and lengths at discarding for the target species. Moreover, the ratio between the discarded catch and marketable catch and the mean annual discard quantities were estimated for the whole catch and for the target species. Finally we modelled the discard quantities based on the landed fraction of the catch and other fishing variables that could be obtained from fishers' logbooks and regular monitoring to gain a more accurate estimate of discard quantities based on the size of landings.

\section{MATERIALS AND METHODS}

\section{Purse seine fishery}

In Greece, the purse seine fishery mainly harvests small pelagic fish. The most common type is the fishery operating during the night using artificial light and targeting sardine (Sardina pilchardus), anchovy (Engraulis encrasicholus), chub mackerel (Scomber japonicus), and bogue (Boops boops) (Vidoris et al. 2001). There is also a very small fishery that uses the purse seine gear during the day. It operates in the same way as the night purse seine fishery but without using the lamp rafts, and targets certain migratory fish, such as bonito (Sarda sarda), Atlantic little tuna (Euthynnus alletteratus), bullet tuna (Auxis rochei), greater amberjack (Seriola dumerili) and dolphin fish (Coryphaena hippurus) (Adamidou 2007).

In this study recordings were made on board purse seine vessels operating during the night, which is the 
main purse seine activity (more than $90 \%$ of the total catch). Adamidou (2007) has provided a full description of the gear, which consists of the main body, the cod-end, and an auxiliary piece of netting attached to the two ends of the main body to facilitate hauling the gear. Fishing with purse seines in Greek waters involves a "mother vessel", a large rowing boat, and several lamp rafts that are released to attract fish once fish aggregations are detected. When a dense aggregation of fish is formed, the "mother vessel" encircles the fish up to the point of the large rowing boat. Then it winches in the purse line, closing the bottom of the seine and forming a bag-shaped net that encloses the fish. Finally, the net is brought alongside the "mother vessel".

According to Greek legislation there is only one type of purse seine license (Kapantagakis 2007). The main prohibitions for operating a purse seine are: i) those included in the EU regulations (e.g. fishing at a distance less than $300 \mathrm{~m}$ from the shore line or in areas shallower than 30 m; EU Regulation 1626/1994), and ii) some restrictions at a national level, such as the closure of the fishery between 15 December and the end of February and the prohibition of fishing two days before and after a full moon. The minimum mesh size for the night seine is $14 \mathrm{~mm}$, the maximum length of the seine is $800 \mathrm{~m}$ and its maximum altitude is 120 $\mathrm{m}$. Most purse-seine vessels operating in the study areas are between 12-24 m long. Small pelagic fish are mainly exploited by the purse seine fleet since pelagic trawlers are prohibited and landings of small pelagics by demersal trawlers are not allowed to exceed $5 \%$ of their total marketable catch. The artisanal fishery, however, shares to some extent the resources harvested by the purse-seine fishery (12\% of the total small pelagic landings, El.Stat. 2011). The majority of vessels are registered in the northern Aegean Sea, and they decrease in number southwards.

The total landings of the purse seine fishery range between 30000 and $50000(43560 \pm 5736) \mathrm{mt}$ for the Aegean sea, and are much lower, between 2000 and 5000 (4069 \pm 956$) \mathrm{mt}$, for the Ionian Sea (Anon 2008). No particular trend in purse seine catches was observed during the study period. At the species level, anchovy and sardine constitute approximately $39 \%$ and $29 \%$ of purse seine landings respectively (Anon 2008), while the rest of the main species constitute less than $10 \%$ each. Anchovy landings are lowest in autumn, while for sardine there is not a constant seasonal pattern. The sardine stock is considered to be fully exploited in the Aegean Sea (Antonakakis et al. 2011), while anchovy is considered to be sustainably fished (SGMED 2009). Information on the current status of the stocks in the Ionian Sea is limited. Decreasing trends in anchovy biomass and landings have been observed in several regions along the northern Mediterranean (i.e. Alboran Sea, N. Spain, Strait of Sicily) during the recent years, with the exception of the Adriatic Sea, where the anchovy stock has fully recovered after its collapse during the 80 s and is considered to be sustainably harvest- ed (STECF 2009). Most Mediterranean sardine stocks are greatly exploited (STECF 2009, Antonakakis et al. 2011 and references therein) and only in a few cases are they considered to be sustainably fished (e.g. the Adriatic Sea stock; STECF 2009).

\section{Sampling}

We used data collected on board commercial purse seine boats from summer 2003 to autumn 2008 in the Aegean (Geographical Sub Area - GSA - 22, according to FAO, General Fisheries Commission for the Mediterranean division) and the eastern Ionian (GSA 20) Seas (Fig. 1). Data were collected during 13 sampling periods carried out at three times of the year: (i) during spring, which is the start of the fishing period; (ii) during summer, which coincides with the recruitment period for sardine (Voulgaridou and Stergiou 2003); and (iii) during autumn, which is the end of the fishing period and coincides with the recruitment period for anchovy (Somarakis et al. 2006). Winter is a closed period for purse seine fisheries in the Greek Seas and thus no sampling was carried out. No sampling was conducted in 2007 or spring 2008 in any of the areas, and neither in autumn 2006 in the Ionian Sea. In each sampling period, at least four vessels (not the same in each sampling), representative of the ones operating in each study area in terms of size and type of construction, were monitored for at least six fishing trips (days) in the Ionian Sea and 18 fishing trips in the Aegean Sea. On each day, usually one or (very occasionally) two hauls were performed. In total, we analysed data from 68 and 281 fishing days in the Ionian and Aegean Seas respectively. More effort was placed on monitoring the Aegean Sea fleet since catches and fishing effort are much lower in the Ionian Sea. Monitored purse seines operated at depths of 18 to $117 \mathrm{~m}$, averaging $52 \mathrm{~m}$ and $56.8 \mathrm{~m}$ in the Aegean and the Ionian Sea respectively.

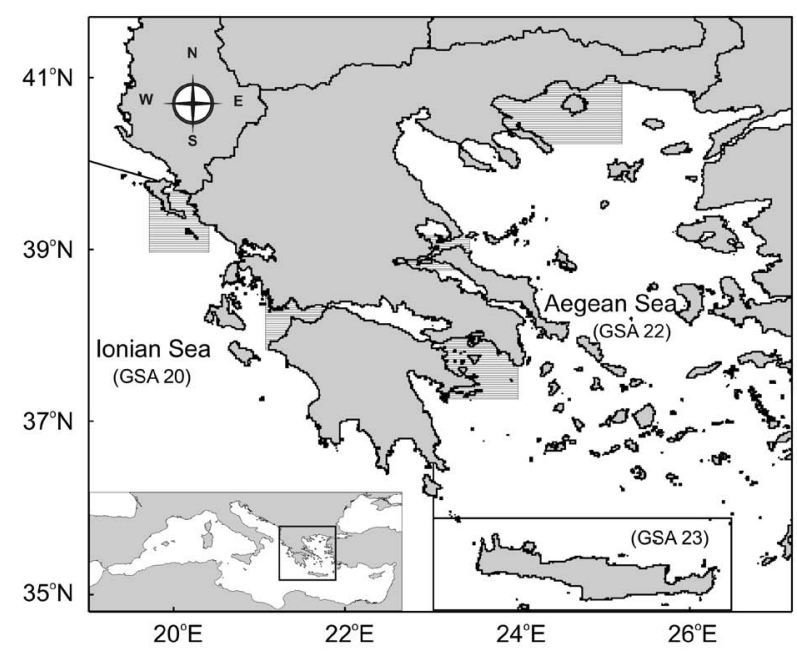

FIG. 1. - Ionian (GSA 20) and Aegean Seas (GSA 22). Shaded regions indicate the areas where data was obtained. 
Fieldwork included identifying the catch composition at the species level and estimating the discarded and landed fractions of the catch following its sorting by the crew. In addition, total length (to the closest $\mathrm{mm}$ ) was recorded for a representative sample of at least 50 individuals by species, both for the discarded and the landed fractions of each species.

The analysis was performed at the trip (day) level, which has been shown to be the best sampling unit for estimating discards (Borges et al. 2005).

\section{Data analysis}

In a first step, we analysed purse seine catches in terms of weight in order to identify a) the target species (the ones comprising the vast majority of the marketable fraction of the catch), b) the species that were occasionally retained, and c) the species that were totally discarded by the purse seiners in the Aegean and Ionian Seas.

For each sampling period and for each region (Aegean and Ionian Seas), we estimated the ratio between the discarded and marketed fraction of the catches. The ratio $(\hat{R})$ and the $95 \%$ confidence intervals (CI) of the discarded fraction were calculated using the following formulas (Cochran 1977):

$$
\begin{gathered}
\hat{R}=\bar{y} / \bar{x}=\sum y_{i} / \sum x_{i} \\
C I(\hat{R})=t_{.05(n-1)} \frac{1}{\sqrt{n} \bar{x}} \sqrt{\frac{\sum y_{i}^{2}-2 \hat{R} \sum y_{i} x_{i}+\hat{R}^{2} \sum x_{i}^{2}}{n-1}}
\end{gathered}
$$

where $y_{i}$ is the discarded fraction of the catch and $x_{i}$ the marketed fraction of the catch in terms of biomass at the $i$ day and $n$ is the number of days. Following the same procedure, we further analysed the ratio between the discards and the marketable fraction for the target species by weight and numbers. Furthermore, the mean annual discarded quantities were estimated based on the estimated ratios and the annual purse seine landings (Anon. 2008).

We also explored the length frequencies of the discarded and marketed fractions as well as the lengths at which $25 \%, 50 \%$ and $75 \%\left(L_{25}, L_{50}\right.$ and $L_{75}$ respectively) of the specimens of each of the target species were discarded. The $L_{50}$ was estimated from the logistic relationship between percentages $P$ of fish discarded at length class $L$ (Machias et al. 2004):

$$
P=\frac{e^{v_{1}+v_{2} * L}}{1+e^{v_{1}+v_{2} * L}}
$$

and the values of $L_{50}, L_{25}, L_{75}$ were estimated from the expressions:

$$
\begin{gathered}
L_{50}=-v_{1} / v_{2} \\
L_{25}=\left[-\operatorname{Ln}(3)-v_{1}\right] / v_{2} \\
L_{75}=\left[\operatorname{Ln}(3)-v_{1}\right] / v_{2}
\end{gathered}
$$

The standard errors and the $95 \%$ confidence intervals of the $L_{50}$ were calculated following the procedures described in Petrakis and Stergiou (1997). We estimated the $L_{50}, L_{25}$, and $L_{75}$ for the whole sampling as well as the $L_{50}$ for the three sampling seasons (spring, summer, autumn). The analysis was performed only for the Aegean Sea because length data from the Ionian Sea were not available.

Finally, generalized additive models (GAMs) (Hastie and Tibshirani 1990) were applied to explore factors affecting the natural log transformed quantities of the discarded catch. GAMs were selected due to their ability to model non-linearities using non-parametric smoothers (Hastie and Tibshirani 1990, Wood 2006). A Gaussian distribution was selected as the best for our data and the natural cubic spline smoother (Hastie and Tibshirani 1990) was used to smooth the independent variables and fit the GAMs. The independent variables used were i) marketable catch (natural log transformed), ii) fishing depth (bottom depth at fishing position), and iii) geographical coordinates at fishing position (latitude, longitude and their interaction). We also considered i) season (spring, summer, autumn), ii) study area (Aegean or Ionian Seas), and iii) boat length $(<24 \mathrm{~m}$, or $>24 \mathrm{~m})$ as factors. A stepwise forward selection was applied to select the final model. Only significant parameters were considered for each model, and validation graphs (e.g. QQ-plot, residual plot versus fitted values and residual plot against the original explanatory variables) were used to detect model misspecification. The final model was selected based on the minimization of the Akaike Information Criterion (AIC) (Burnham and Anderson 2002). Specifically, the model with the lowest AIC value best explained the variability of the data, while models with $\triangle \mathrm{AIC}<2$ $\left(\triangle \mathrm{AIC}=\mathrm{AIC}_{\mathrm{i}}-\mathrm{AIC}_{\min }\right)$ would be considered of equal strength (Burnham and Anderson 2002). The 'mgcv' library in the $\mathrm{R}$ statistical software ( $\mathrm{R}$ Development Core Team 2010) was used to apply the GAMs.

\section{RESULTS}

Five species ( $S$. pilchardus, E. encrasicolus, Sardinella aurita, B. boops and S. japonicus) in the Aegean Sea represented $97 \%$ of the marketable catch (Table 1A); these were considered as the target species. The rest of the marketable fraction (3\%) was constituted by 55 species that were accidentally caught and occasionally retained (Table 1A). In the Ionian Sea, the target species of the purse seine fishery constituted $98.1 \%$ of the marketable fraction and were the same as in the Aegean Sea, with the exception of picarel (Spicara smaris) instead of mackerel (S. japonicus) (Table 1B). There were only 12 occasionally marketable species, which is much less than in the Aegean Sea purse seine fishery (Table 1B). In the Aegean Sea, 76 species were always discarded (Table 2A), while this number was much lower in the Ionian Sea (15 species; Table 2B). Several high-price species (e.g., Lophius piscatorius, Thunnus alalunga, 
TABLE 1. - Marketable species (target species and occasionally caught species) present in the purse seine fisheries catches in the Aegean and Ionian Seas. ${ }^{\mathrm{a}}$ and ${ }^{\mathrm{b}}$ indicate crustacean and cephalopod species respectively.

\author{
A. Aegean Sea \\ Target species ( $97 \%$ of marketable catch) \\ Sardina pilchardus \\ Engraulis encrasicolus \\ Occasionally caught species \\ Auxis rochei \\ Belone belone gracilis \\ Caranx crysos \\ Caranx rhonchus \\ Citharus linguatula \\ Coryphaena hippurus \\ Dactylopterus volitans \\ Dentex dentex \\ Diplodus annularis \\ Diplodus vulgaris \\ Euthynnus alletteratus \\ Lithognathus mormyrus \\ Liza saliens \\ Lophius budegassa \\ Merluccius merluccius \\ Mugil cephalus \\ Mullus barbatus \\ M. surmuletus \\ Oblada melanura
}

B. Ionian Sea

Target species (98.1\% of marketable catch)

Sardina pilchardus

Engraulis encrasicolus

Occasionally caught species

Centracanthus cirrus

Diplodus annularis

Lepidopus caudatus

Scomber scombrus
Sardinella aurita

Scomber japonicus

Pagellus erythrinus

Pagrus pagrus

Pomatomus saltator

Sarda sarda

Sarpa salpa

Sciaena umbra

Scomber scombrus

Scorpaena scrofa

Solea kleini

S. lascaris

S. vulgaris

Sparus aurata

Sphyraena sphyraena

Spicara maena

S. smaris

Spondyliosoma cantharus

Sprattus sprattus

Trachinotus ovatus

Trachinus draco
Boops boops

Trachurus mediterraneus

T. picturatus

T. trachurus

Trigla lucerna

Trigloporus lastoviza

Trisopterus minutus capelanus

Uranoscopus scaber

Xiphias gladius

Zeus faber

Parapenaeus longirostris ${ }^{\mathrm{a}}$

Penaus kerathurus ${ }^{\mathrm{a}}$

Illex coindetii ${ }^{\mathrm{b}}$

Loligo vulgaris ${ }^{\mathrm{b}}$

Octopus vulgaris ${ }^{\mathrm{b}}$

Sepia officinalis ${ }^{\mathrm{b}}$

Sepiolidae ${ }^{\mathrm{b}}$

Todarodes sagittatus ${ }^{\mathrm{b}}$

Sardinella aurita

Boops boops

Spicara smaris

S. japonicus

Sparus aurata

Sphyraena sphyraena

Thunnus alalunga
Trachurus mediterraneus

T.trachurus

Illex coindetii ${ }^{\mathrm{b}}$

Loligo vulgaris ${ }^{\mathrm{b}}$

TABLE 2. - Totally discarded species in the purse seine fisheries in the Aegean and Ionian Seas. ${ }^{\mathrm{a}}$ and ${ }^{\mathrm{b}}$ indicate crustacean and cephalopod species respectively.

\begin{tabular}{|c|c|c|}
\hline \multicolumn{3}{|l|}{ A. Aegean Sea } \\
\hline Arnoglossus laterna & Hipросатриs hipросатриs & S. scriba \\
\hline A. rueppelli & Hirundichthys rondeletii & Stephanolepis diaspros \\
\hline A. thori & Lepidopus caudatus & Symphodus cinereus \\
\hline Aspitrigla cuculus & Lepidotrigla cavillone & S. mediterraneus \\
\hline Atherina boyeri & Lesueurigobius friesii & S. ocellatus \\
\hline A. hepsetus & L. suerii & S. rostratus \\
\hline Blennius ocellaris & Lophius piscatorius & S. tinca \\
\hline Capros aper & Merlangius merlangus euxinus & Symphodus sp. \\
\hline Cepola rubescens & Microchirus ocellatus & Syngnathus acus \\
\hline Chlorotocus crassicornis & M. variegatus & S. typhle \\
\hline Chromis chromis & Micromesistius poutassou & Synodus saurus \\
\hline Conger conger & Monochirus hispidus & Thunnus alalunga \\
\hline Coris julis & Myctophidae & Torpedo nobiliana \\
\hline Dasyatis pastinaca & Ophidion barbatum & Xyrichthys novacula \\
\hline Deltentosteus quadrimaculatus & Pagellus acarne & Goneplax rhomboides ${ }^{\mathrm{a}}$ \\
\hline Diplodus puntazzo & $P$. bogaraveo & Liocarcinus depurator ${ }^{\mathrm{a}}$ \\
\hline D. sargus & Raja montagui & Majidae $^{\mathrm{a}}$ \\
\hline Echelus myrus & $R$. naevus & Scyllarus arctus $^{\mathrm{a}}$ \\
\hline Echeneis naucrates & $R$. polystigma & Squilla mantis ${ }^{\mathrm{a}}$ \\
\hline Etrumeus teres & Scorpaena notata & Alloteuthis media ${ }^{\mathrm{b}}$ \\
\hline Eutrigla gurnardus & S. porcus & Eledone cirrhosa ${ }^{\mathrm{b}}$ \\
\hline Gaidropsarus mediterraneus & Scorpaena spp. & E. moschata \\
\hline Glossanodon leioglossus & Scyliorhinus canicula & Sepia elegans ${ }^{\mathrm{b}}$ \\
\hline Gobius niger & Seriola dumerili & Sepietta spp. ${ }^{\mathrm{b}}$ \\
\hline Gobius sp. & Serranus cabrilla & \\
\hline Gymnammodytes cicerelus & S. hepatus & \\
\hline \multicolumn{3}{|l|}{ B. Ionian Sea } \\
\hline Atherina hepsetus & Labrus viridis & Serranus hepatus \\
\hline Belone belone gracilis & Mullus surmuletus & Solea vulgaris \\
\hline Caranx crysos & Pagellus acarne & Spondyliosoma cantharus \\
\hline Chromis chromis & S. scriba & Synodus saurus \\
\hline Coris julis & Scorpaena scrofa & Alloteuthis media ${ }^{\mathrm{b}}$ \\
\hline
\end{tabular}


TABLE 3. - Discards on marketable biomass ratios and standard errors calculated for each sampling period for the target species of the purse seine fishery in the Aegean (A) and Ionian (B) Seas. Estimated amounts of annual discards per species are also shown. TD: totally discarded; -: not represented in the catch.

\begin{tabular}{|c|c|c|c|c|c|c|c|c|}
\hline Area & Year & Season & $\begin{array}{c}\text { Engraulis } \\
\text { encrasicolus }\end{array}$ & $\begin{array}{c}\text { Sardina } \\
\text { pilchardus }\end{array}$ & $\begin{array}{c}\text { Sardinella } \\
\text { aurita }\end{array}$ & $\begin{array}{l}\text { Boops } \\
\text { boops }\end{array}$ & $\begin{array}{l}\text { Scomber } \\
\text { japonicus }\end{array}$ & $\begin{array}{c}\text { Spicara } \\
\text { smaris }\end{array}$ \\
\hline \multicolumn{9}{|c|}{ A. Aegean Sea } \\
\hline & \multirow[t]{2}{*}{2003} & Summer & $<0.01$ & $<0.01$ & $0.18 \pm 0.12$ & $<0.01$ & $<0.01$ & \\
\hline & & Autumn & $0.01 \pm 0$ & $<0.01$ & $1.71 \pm 0.74$ & $0.33 \pm 0.19$ & $<0.01$ & \\
\hline & \multirow[t]{3}{*}{2004} & Spring & $<0.01$ & $0.01 \pm 0.01$ & $0.24 \pm 0.14$ & $6 \pm 0.33$ & $<0.01$ & \\
\hline & & Summer & $<0.01$ & $<0.01$ & $<0.01$ & $<0.01$ & $0.01 \pm 0.01$ & \\
\hline & & Autumn & TD & $0.03 \pm 0.01$ & $0.44 \pm 0.05$ & $0.1 \pm 0.05$ & $<0.01$ & \\
\hline & \multirow[t]{3}{*}{2005} & Spring & $<0.01$ & $<0.01$ & $0.01 \pm 0.01$ & $1.81 \pm 0.11$ & $<0.01$ & \\
\hline & & Summer & $<0.01$ & $<0.01$ & $0.12 \pm 0.11$ & $0.22 \pm 0.01$ & $<0.01$ & \\
\hline & & Autumn & $<0.01$ & $<0.01$ & $0.3 \pm 0.17$ & $0.2 \pm 0.14$ & $<0.01$ & \\
\hline & \multirow[t]{3}{*}{2006} & Spring & $<0.01$ & $0.04 \pm 0.01$ & $0.01 \pm 0$ & TD & $<0.01$ & \\
\hline & & Summer & $<0.01$ & $<0.01$ & $0.14 \pm 0.09$ & $0.18 \pm 0.06$ & $<0.01$ & \\
\hline & & Autumn & $<0.01$ & $<0.01$ & $10.8 \pm 4.74$ & $<0.01$ & $0.01 \pm 0$ & \\
\hline & \multirow[t]{2}{*}{2008} & Summer & $<0.01$ & $<0.01$ & $0.99 \pm 0.69$ & $<0.01$ & $<0.01$ & \\
\hline & & Autumn & $<0.01$ & $<0.01$ & $4.83 \pm 3.3$ & $0.28 \pm 0.21$ & $<0.01$ & \\
\hline & \multicolumn{2}{|c|}{ Mean ratio } & $<0.01$ & 0.01 & 0.13 & 0.28 & $<0.01$ & \\
\hline & \multicolumn{2}{|c|}{ Mean annual discards estimate (mt) } & ) 11.00 & 63.06 & 203.40 & 625.29 & 6.17 & \\
\hline \multicolumn{9}{|c|}{ B. Ionian Sea } \\
\hline & \multirow[t]{2}{*}{2003} & Summer & $0.04 \pm 0.03$ & $<0.01$ & $<0.01$ & $7.75 \pm 4$ & & - \\
\hline & & Autumn & - & $<0.01$ & $<0.01$ & - & & - \\
\hline & \multirow[t]{3}{*}{2004} & Spring & $<0.01$ & $<0.01$ & TD & $0.01 \pm 0$ & & $<0.01$ \\
\hline & & Summer & $<0.01$ & $<0.01$ & $<0.01$ & $<0.01$ & & TD \\
\hline & & Autumn & TD & $<0.01$ & TD & - & & - \\
\hline & \multirow[t]{3}{*}{2005} & Spring & $<0.01$ & $<0.01$ & TD & TD & & $<0.01$ \\
\hline & & Summer & $<0.01$ & $<0.01$ & - & $<0.01$ & & $<0.01$ \\
\hline & & Autumn & $<0.01$ & $<0.01$ & $\mathrm{TD}$ & $<0.01$ & & - \\
\hline & \multirow[t]{2}{*}{2006} & Spring & $<0.01$ & $<0.01$ & TD & TD & & $<0.01$ \\
\hline & & Summer & $<0.01$ & $<0.01$ & TD & - & & - \\
\hline & \multirow[t]{2}{*}{2008} & Summer & $<0.01$ & $<0.01$ & $0.31 \pm 0.33$ & $<0.01$ & & - \\
\hline & & Autumn & - & $<0.01$ & $1.46 \pm 0.99$ & $<0.01$ & & - \\
\hline & \multicolumn{2}{|c|}{ Mean ratio } & $<0.01$ & $<0.01$ & 0.28 & $<0.01$ & & 0.02 \\
\hline & \multicolumn{2}{|c|}{ Mean annual landings (mt) } & 744.94 & 1289.99 & 95.67 & 280.84 & & 48.93 \\
\hline & \multicolumn{2}{|c|}{ Mean annual discards estimate (mt) } & 1.43 & $<0.01$ & 27.23 & 0.79 & & 1.05 \\
\hline
\end{tabular}

Sorpaena scrofa) were occasionally discarded because of their very low catches of undersized individuals. Several benthic species were recorded in the catch composition of the purse seines, but their contribution to the total catch was very low, i.e. $0.6 \%$ and $0.1 \%$ in the Aegean and the Ionian Seas respectively. The ratio between the discards and the marketable fraction, considering all species, ranged from $<0.01$ to 0.15 (Fig. 2) with an average of 0.048 in the Aegean Sea. In the Ionian Sea this ratio ranged from $<0.01$ to 0.09 (Fig. 2) with an average of 0.023 . These results indicate that discards constituted only $4.6 \%$ and $2.2 \%$ of the total catch in the Aegean and Ionian Seas respectively. Based on these results and on mean annual landings, the total discards could be estimated to be $2091 \mathrm{mt}$ and $94 \mathrm{mt}$ for the Aegean and Ionian Seas respectively.

Discard ratios for target species reveal varying discarding practices for each species in the different study areas and seasons. Ratio values estimated based on biomass (Table 3 ) were in most cases slightly lower than ratios estimated based on numbers of discarded individuals (Table 4) because discards mostly comprise small specimens. This difference aside, both ratios give a similar picture for each species. Discard ratios showed small variations among sampling periods and were rather low for mackerel (in the Aegean Sea),

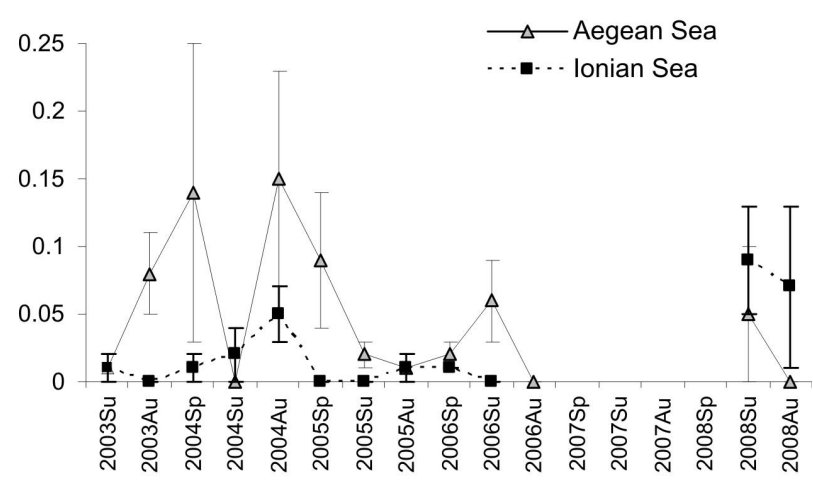

FIG. 2. - Discards on marketable ratio (mean daily values and their s.e.) during the different sampling periods for the Aegean and Ionian Seas. Sp: spring; Su: summer; Au: autumn.

anchovy and especially sardine, while they fluctuated from almost zero to total discarding for the rest of the species in both areas (Tables 3, 4). Based on these ratios, it is apparent that anchovy and sardine are the main species targeted by the fishers, while the rest of the species constitute a supplementary and/or alternative resource when the catch of these two species is not satisfactory in terms of total biomass, individual sizes or market prices. Seasonal fluctuations were observed, 
PURSE SEINE FISHERY DISCARDS IN THE EASTERN MEDITERRANEAN • 567

TABLE 4. - Discards on marketable abundance ratios and their standard errors for the target species of the purse seine fishery in the Aegean (A) and Ionian (B) Seas, calculated for each sampling period. TD: totally discarded; -: not represented in the catch.

\begin{tabular}{|c|c|c|c|c|c|c|c|c|}
\hline Area & Year & Season & $\begin{array}{c}\text { Engraulis } \\
\text { encrasicolus }\end{array}$ & $\begin{array}{c}\text { Sardina } \\
\text { pilchardus }\end{array}$ & $\begin{array}{l}\text { Sardinella } \\
\text { aurita }\end{array}$ & $\begin{array}{l}\text { Boops } \\
\text { boops }\end{array}$ & $\begin{array}{c}\text { Scomber } \\
\text { japonicus }\end{array}$ & $\begin{array}{l}\text { Spicara } \\
\text { smaris }\end{array}$ \\
\hline A. Ae & $\begin{array}{l}\mathrm{a} \\
2003 \\
2004\end{array}$ & $\begin{array}{l}\text { Summer } \\
\text { Autumn } \\
\text { Spring } \\
\text { Summer } \\
\text { Autumn } \\
\text { Spring } \\
\text { Summer } \\
\text { Autumn } \\
\text { Spring } \\
\text { Summer } \\
\text { Autumn } \\
\text { Summer } \\
\text { Autumn }\end{array}$ & $\begin{array}{c}<0.01 \\
0.03 \pm 0.01 \\
<0.01 \\
<0.01 \\
\text { TD } \\
0.01 \pm 0 \\
<0.01 \\
<0.01 \\
<0.01 \\
<0.01 \\
<0.01 \\
<0.01 \\
<0.01\end{array}$ & $\begin{array}{l}<0.01 \\
<0.01 \\
0.01 \pm 0 \\
<0.01 \\
0.03 \pm 0 \\
<0.01 \\
0.02 \pm 0 \\
<0.01 \\
0.06 \pm 0 \\
<0.01 \\
<0.01 \\
<0.01 \\
<0.01\end{array}$ & $\begin{array}{c}0.22 \pm 0.02 \\
2.32 \pm 0.25 \\
0.25 \pm 0.03 \\
<0.01 \\
0.63 \pm 0.01 \\
0.02 \pm 0 \\
0.54 \pm 0.03 \\
0.73 \pm 0.04 \\
0.01 \pm 0 \\
0.14 \pm 0.01 \\
95 \pm 14.11 \\
0.97 \pm 0.06 \\
6.06 \pm 0.34\end{array}$ & $\begin{array}{c}<0.01 \\
0.8 \pm 0.16 \\
19.96 \pm 3.4 \\
<0.01 \\
0.14 \pm 0 \\
3.88 \pm 0.23 \\
0.25 \pm 0.01 \\
1.37 \pm 0.07 \\
\text { TD } \\
0.32 \pm 0.02 \\
0.01 \pm 0 \\
<0.01 \\
0.5 \pm 0.03\end{array}$ & $\begin{array}{c}0.12 \pm 0.01 \\
<0.01 \\
<0.01 \\
0.03 \pm 0 \\
<0.01 \\
0.01 \pm 0 \\
0.03 \pm 0 \\
<0.01 \\
<0.01 \\
<0.01 \\
0.65 \pm 0.06 \\
<0.01 \\
<0.01\end{array}$ & \\
\hline B. Ion & $\begin{array}{l}2003 \\
2004\end{array}$ & $\begin{array}{l}\text { Summer } \\
\text { Autumn } \\
\text { Spring } \\
\text { Summer } \\
\text { Autumn } \\
\text { Spring } \\
\text { Summer } \\
\text { Autumn } \\
\text { Spring } \\
\text { Summer } \\
\text { Summer } \\
\text { Autumn }\end{array}$ & $\begin{array}{c}0.04 \pm 0.01 \\
- \\
<0.01 \\
<0.01 \\
\text { TD } \\
<0.01 \\
<0.01 \\
<0.01 \\
<0.01 \\
<0.01 \\
<0.01 \\
-\end{array}$ & $\begin{array}{l}<0.01 \\
<0.01 \\
<0.01 \\
<0.01 \\
<0.01 \\
<0.01 \\
<0.01 \\
<0.01 \\
<0.01 \\
<0.01 \\
<0.01 \\
<0.01\end{array}$ & $\begin{array}{c}<0.01 \\
<0.01 \\
\text { TD } \\
<0.01 \\
\text { TD } \\
\text { TD } \\
- \\
\text { TD } \\
\text { TD } \\
\text { TD } \\
0.46 \pm 0.12 \\
1.44 \pm 0.73\end{array}$ & $\begin{array}{c}19.33 \pm 19.33 \\
- \\
0.01 \pm 0.01 \\
<0.01 \\
- \\
\text { TD } \\
<0.01 \\
<0.01 \\
\text { TD } \\
- \\
<0.01 \\
<0.01\end{array}$ & & $\begin{array}{c}- \\
- \\
<0.01 \\
\text { TD } \\
- \\
<0.01 \\
<0.01 \\
- \\
<0.01 \\
- \\
- \\
-\end{array}$ \\
\hline
\end{tabular}

TABLE 5. - Lengths (mm) at which $25 \%, 50 \%$ and $75 \%\left(L_{25}, L_{50}\right.$ and $L_{75}$ respectively) of the individuals were discarded for the target species in the Aegean Sea, calculated for the whole dataset. The $\mathrm{L}_{50}$ calculated for the three seasons is also shown. CI \pm : $95 \%$ confidence intervals for $L_{50} ; \mathrm{v}_{1}, \mathrm{~V}_{2}$ : parameters of the logistic equation. All results shown were significant with p-value $<0.001$, unless NS (non-significant) is indicated.

\begin{tabular}{|c|c|c|c|c|c|c|c|c|c|c|}
\hline Species & $L_{50}$ & CI- & CI+ & $\begin{array}{c}\text { Total } \\
\mathrm{v}_{1}\end{array}$ & $v_{2}$ & $L_{25}$ & $L_{75}$ & $\underset{L_{50}}{\text { Spring }}$ & $\underset{L_{50}}{\text { Summer }}$ & $\underset{L_{50}}{\text { Autumn }}$ \\
\hline Boops boops & 145.7 & 145.5 & 145.9 & 6.14 & 0.042 & 171.8 & 119.7 & 182.6 & 144.1 & 144.7 \\
\hline Engraulis encrasicolus & 66.7 & 66.2 & 67.1 & 2.51 & 0.038 & 95.9 & 37.4 & 77.9 & 60.4 & 80.6 \\
\hline Sardina pilchardus & 76.6 & 76.3 & 76.9 & 4.02 & 0.053 & 97.5 & 55.7 & 81.5 & 98.1 & NS \\
\hline Sardinella aurita & 173.4 & 173.2 & 173.6 & 4.07 & 0.023 & 220.2 & 126.7 & NS & 162.5 & 207.5 \\
\hline Scomber japonicus & 133.7 & 132.9 & 134.4 & 5.18 & 0.039 & 162.0 & 105.3 & 149.1 & 126.7 & 117.4 \\
\hline
\end{tabular}

which in some cases were related to the recruitment period of the species. For example, in the Ionian Sea, anchovy was totally discarded or there were no catches at all (i.e. it was not targeted by the fishers) in several sampling periods in autumn (i.e., the recruitment period for anchovy; Table 3B, 4B).

The length frequencies of the discarded and marketable fractions (Fig. 3) provide a good overview of the sizes retained and discarded per target species for each season in the Aegean Sea, for which length data were available. It is obvious that for all species it is the larger individuals that are retained, with the exception of round sardinella for which an extended overlap of the length frequencies of the discarded and marketable fractions is observed in all seasons. For the rest of the species, this overlap is limited and is almost nonexistent during their recruitment periods. The two fractions (marketable and discards) are constituted by different age classes, especially for short lived species, during the recruitment period, i.e. autumn for anchovy and summer for sardine (Fig. 3).
Seasonal fluctuations are also observed in the lengths at which $50 \%$ of the individuals $\left(\mathrm{L}_{50}\right)$ were discarded in the Aegean Sea (Table 5). The $\mathrm{L}_{50}$ was found to be lower than the minimum landing size (MLS) defined by the EU regulation 1967/2006 for anchovy $(\mathrm{MLS}=90 \mathrm{~mm})$, sardine $(\mathrm{MLS}=110 \mathrm{~mm})$ and mackerel (MLS=180 mm) in all seasons, while it was higher for bogue and round sardinella, the MLS of which are defined by Greek legislation. Note, however, that some of the aforementioned MLSs had not yet been established in Greece during the survey period. Specifically, there was no MLS for sardine, while for mackerel the MLS was much lower $(120 \mathrm{~mm})$ during the survey period compared to the current one (180 mm).

The final GAM included marketable catch, and the interaction between latitude and longitude as explanatory variables (Table 6). The effects of boat length, season, study area and fishing depth were not significant and these parameters were not included in the final model. The deviance explained was relatively low (33.7\%; Table 6), implying low precision in the 

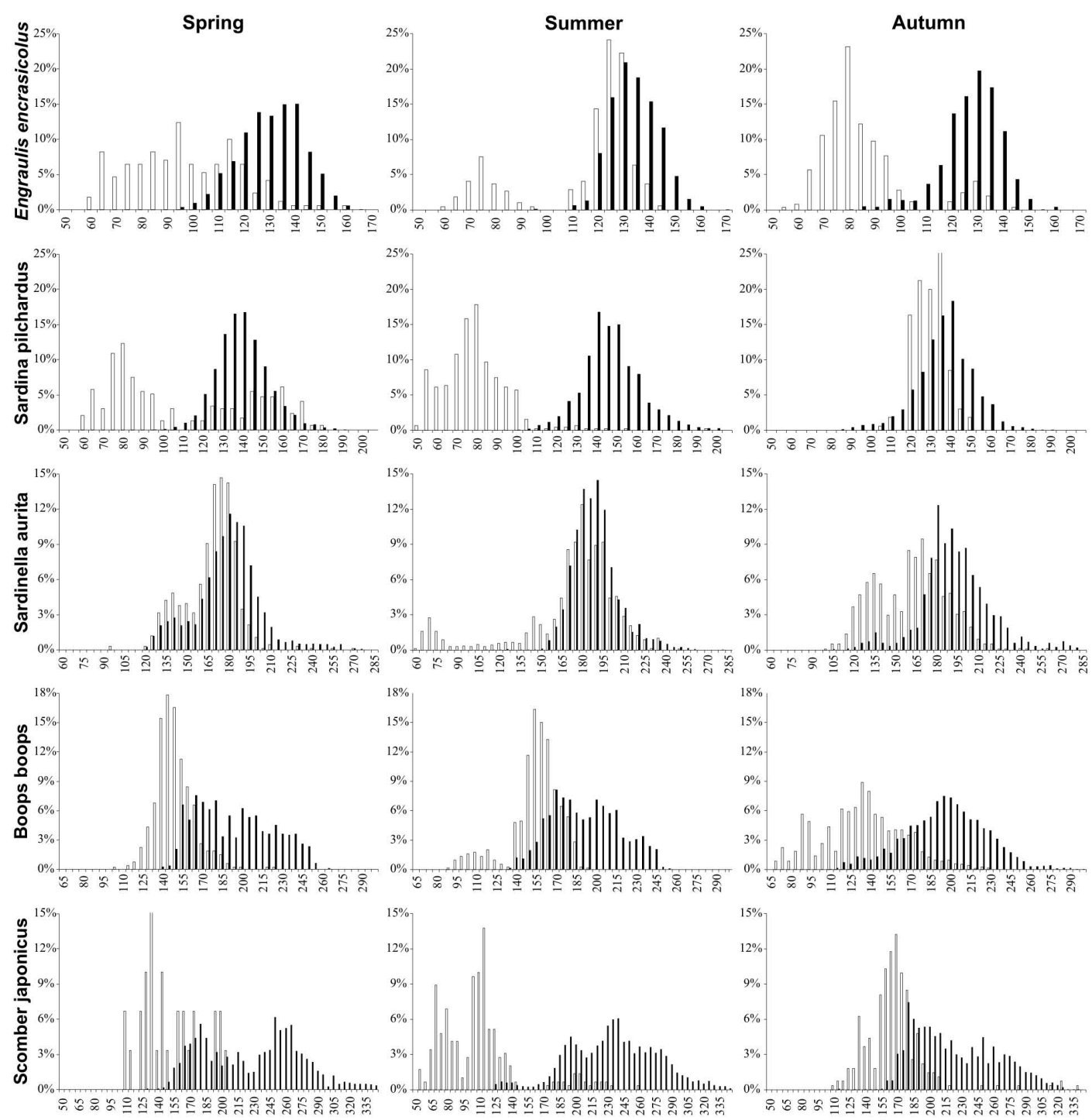

Length frequencies $(\mathrm{mm})$

FIG. 3. - Length frequencies of the marketable (black columns) and discarded (white columns) fractions of the catch for the five target species in the Aegean Sea.

TABLE 6. - Analysis of deviance for GAMs of natural log transformed discarded quantities. The forward selection and final model are shown. Res. Df, residual degrees of freedom; Res. Dev., residual deviance; Dev. explained, \% Deviance explained; AIC, Akaike Information Criterion; s, smooth function; Lon, longitude at fishing position; Lat, latitude at fishing position; marketable, natural logarithmic transformation of the marketable fraction of the catch; * denotes interaction.

\begin{tabular}{lccccc}
\hline Model & Res. Df & Res. Dev. & Dev. explained & AIC & P-value \\
\hline Null & 348.00 & 4704.86 & $0 \%$ & 1902.27 & \\
s(Lat*Lon) & 329.53 & 3508.34 & $25.4 \%$ & 1836.80 & $<0.001$ \\
s(Lat*Lon)+s(Marketable) & 318.54 & 3121.49 & $33.7 \%$ & 1817.99 & $<0.001$ \\
\hline
\end{tabular}

estimates of the discarded fraction, possibly due to the varying discarding practices, as also indicated by the previous results. The interaction between latitude and longitude explained a larger amount of the deviance compared to the marketable catch; however, it did not provide a clear spatial pattern. Zero or negative effects (i.e. low discard quantities) were apparent at higher latitudes (e.g. in the N. Aegean Sea and the N. Ionian
Sea; Fig. 4), while mixed effects (including high positive effects locally) were observed for the remaining values of the geographical coordinates. Low values of marketable catch $(<400 \mathrm{~kg})$ had a negative effect on discards (i.e. low discard quantities; Fig. 4). High values of marketable quantities $(>3270 \mathrm{~kg})$ had a similar effect, while the effect of intermediate marketable values fluctuated from slightly positive to zero. 

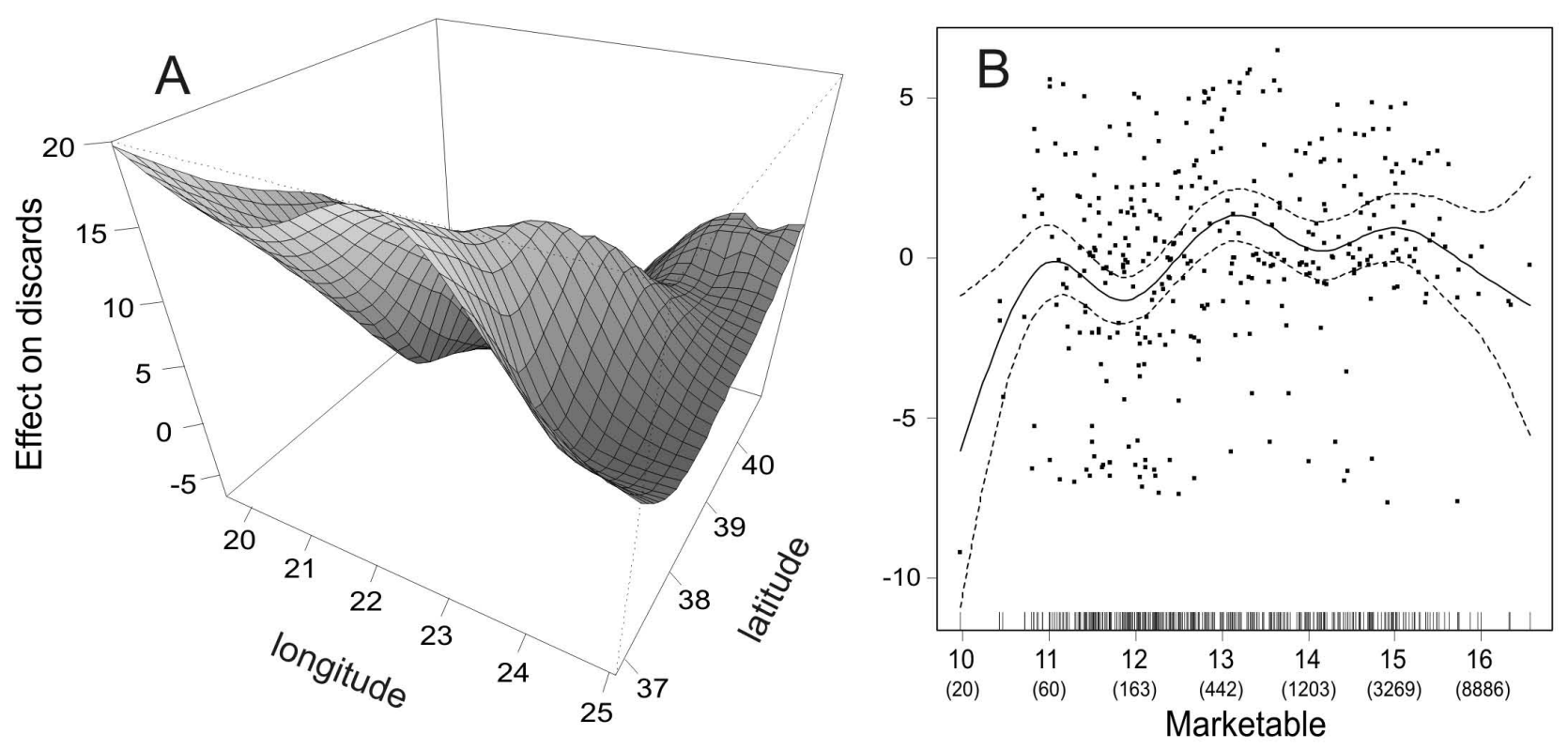

FIG. 4. - Estimated smooth terms of the parameters contributing to the GAMs for natural log transformed discarded quantities. A: Effect of the interaction between latitude and longitude, B: Effect of the marketable catch (natural log transformed values in g; $95 \%$ confidence intervals are shown with dotted lines. Points indicate residuals. Original values in $\mathrm{kg}$ are indicated in parentheses).

\section{DISCUSSION}

We analysed data collected on board commercial purse seine vessels in two areas (Aegean and Ionian Seas) in the eastern Mediterranean Sea in order to describe the discarded fraction of the catch and shed light on discarding practices. In each area, only five species comprised the vast majority of landings ( $>97 \%)$, confirming the homogeneity of the catch and the high selectivity of the gear. This number is very low compared to other Mediterranean fisheries that are multi-species in nature (Lleonart and Maynou 2003). The high selectivity of the purse seine fishery was also confirmed by the low discard rates. The estimated ratios $(\approx 4.6 \%$ and $\approx 2.2 \%$ of the total catch for the Aegean and Ionian fisheries respectively) were higher but comparable to the weighted global average for purse seines $(1.6 \%)$ targeting small pelagics, which are included in the list of "fisheries and fishing areas with very low to negligible discard rates" as reported by Kelleher (2005). Similar studies in the broad area reveal low discard ratios in the north eastern Black Sea (1\%; Şahin et al. 2008) and the eastern Mediterranean (no discards in the Lebanon purse seine fishery; Bariche et al. 2006), while higher ratios have been reported for purse seine fisheries in the Adriatic Sea (2-15\%, including results from midwater trawls analyses; Santojanni et al. 2005), the western Mediterranean Sea (13-15\%; Kelleher 2005) and south Portugal (27\%; Borges et al. 2001). Existing studies on midwater trawls also report higher discard rates in the Turkish Black Sea (5.1\%; Kelleher 2005) and the Adriatic (up to 15\%; Santojanni et al. 2005). Moreover, the discard ratio of the purse seine fishery in the Aegean and Ionian Seas was much lower than that of the demersal trawl fishery (38-49\%; Machias et al. 2001, Tsagarakis et al. 2008) as well as that of the artisanal fishery in Greek waters (10\%; Tzanatos et al. 2007).

Kelleher (2005) reports that, even though purse seine discards may be low as a percentage, the discarded quantities may still be high because purse seine catches can be large. This is particularly true for productive upwelling ecosystems where very large catches of the dominant small pelagics can be taken, but these quantities may not be so high in other types of ecosystems, like the one of the eastern Mediterranean, which is considered to be among the most oligotrophic of the world (Stergiou et al. 1997). A draft estimate of discarded quantities based on Greek landings would be $2185 \mathrm{mt}$ in annual base, approximately $1 / 10$ of the total demersal trawl discards (19851 mt, estimated based on: Machias et al. 2001, Anon 2008, Tsagarakis et al. 2008). This is quite low and even if we consider omitting discards, it would have little effect on stock assessment estimates due to the high catches and abundance of small pelagics (Santojanni et al. 2005). In contrast, in certain purse seine fisheries, in which slippage takes place, mortality of slipping fish may constitute an important fraction of the catch; Stratoudakis and Marcalo (2002) estimated that slipping fish make up 69\% of the catch in Portuguese purse seines targeting sardine. Mortality of slipping fish (or non-catch mortality) is considered to be a source of error for stock assessment and fisheries management (Mitchell et al. 2002, Stratoudakis and Marcalo 2002, Huse and Vold 2010) and it is a knowledge gap for all gears. Most of this mortality, which mainly occurs due to injuries of the escaping fish, may be species-specific, density-dependent 
(Huse and Vold 2010, Marcalo et al. 2010) and may even vary across space and time. Hence, for selective gears with low discard ratios, like purse seines, more effort should be placed on estimating the mortality rate at sea instead of analysing the discard mortality further, especially when the budget is limited.

Discard ratios in both the Aegean and Ionian Seas fluctuated greatly and didn't show any constant trends among years or seasons. Discarding is a process decided on board based on the size of the catch, market prices of species and length composition, and takes into account legal, technical and environmental constraints (Machias et al. 2004, Rochet and Trenkel 2005). The varying fishing and discarding practices and the complexity of factors affecting decisions on discarding are the reasons behind the observed fluctuations.

An important factor affecting discarding at the species level is recruitment period. The short-lived species in particular, like many of the small pelagics, show age (and length) stratification of the population during the recruitment period, leading to seasonal differences in discarding practices. As a consequence of the dominance of small sized individuals, anchovy was totally discarded or it was not present in the catch (obviously because it was not targeted by the fishers) in several sampling periods during autumn, i.e., its recruitment period (Somarakis et al. 2006). The fact that different species have different recruitment periods may partially explain the absence of seasonal trends in discard ratios and/or total catches.

Furthermore, discarding often depends on the species and size composition, their relative biomass and the total amount of the rest of the catch. Santojanni et al. (2005) identified specific thresholds in sardine mean length and in anchovy total catch that affected sardine discards in the Adriatic Sea. Such practices are also expected to take place in the Greek purse seine fisheries, especially for species which have higher and less constant discarding rates or are often absent from the catch (e.g. bogue, round sardinella and picarel). Discarding of anchovy and sardine (and mackerel in the Aegean Sea) is usually negligible, indicating that these are the main species targeted by the fishery. It is noteworthy that bogue and picarel may have higher market prices than anchovy and sardine (the average values in euros $/ \mathrm{kg}$ for the study period were: Anchovy: 1.54; Sardine: 1.17; Chub mackerel: 1.99; Bogue: 1.83; Picarel: 1.91; Round sardinella: 1.13); however, they are less targeted by the purse seiners due to their lower abundance and because during the study period they were also being exploited by other fishing gears, such as boat seines, which are now prohibited in Greek waters. These species constitute a supplementary income source for the fishers and they are probably retained to a higher degree when the rest of the catch is not satisfactory or when current market demand is high. This kind of practice is quite common in multispecies fisheries in Greece (Machias et al. 2001, Tzanatos et al. 2007, Tsagarakis et al. 2008).
Length frequencies of the discarded and marketable fractions provide additional information on discarding practices. For most species, size is the main factor affecting whether it is discarded or not, which is shown by the small overlap between the length frequencies of the two fractions. However, in certain species these length frequencies overlap greatly, which shows that discarding of these species is probably more affected by the rest of the catch than the size composition of the species itself. This is particularly true for round sardinella, a species for which a northwards expansion in its spatial distribution followed by a population outburst has recently been observed (Tsikliras 2008) and for which market demand is still low.

The lengths at which $50 \%$ of the individuals were discarded $\left(L_{50}\right)$ were relatively low for anchovy, sardine and mackerel (i.e. the three main target species). Even though the grant majority of landed individuals were larger that their minimum landing sizes (MLS), as revealed by the length frequencies, the estimated $L_{50}$ for the three species and even $L_{25}$ for sardine and mackerel were well below their MLSs. However, for sardine a MLS was established after the end of the sampling and for mackerel the MLS increased from $120 \mathrm{~mm}$ to 180 $\mathrm{mm}$. Nevertheless, the existing legal measurements of anchovy didn't seem to prevent fishers from landing undersized fish. Further samplings are needed to reveal whether recently established MLSs are taken into account in decisions on discarding and whether stricter inspection by the authorities is required. Low compliance with MLS regulations has also been mentioned for other types of Mediterranean fisheries (Stergiou et al. 2009, Cetinić et al. 2011). For the round sardinella and bogue, lengths at discarding were relatively high (larger than their MLS) because, as mentioned before, they constitute a supplementary income source and/ or there is only market demand for relatively large individuals.

Interestingly, the discarded quantities were not found to be related to factors such as boat length, season or fishing depth. The interaction between latitude and longitude explained much of the variability in discarded quantities. The geographical coordinates may reflect the effect of other factors considered and of factors that are not directly taken into account, such as community composition, distance from the coast, productivity gradients etc., and can contribute to making a good estimate of discards. In our case, no clear spatial gradient was revealed apart from the fact that the northern parts of the Aegean and Ionian Seas stood out as regions with low discards. This could be because there is a north-south gradient, where the anchovy/sardine complex is progressively replaced by the bogue/ picarel complex moving southwards (Stergiou et al. 1997). Based on our previous results, the anchovy/sardine complex has much lower discards rates than the bogue/picarel complex.

Moreover, discarded quantities were found to be low when the quantities of the marketable fraction of 
the catch were either low or high, while in intermediate marketable catches, the discarded fraction was higher. It is assumed that in low catches, fishers land most of the catch (i.e., low discards), even though it may consist of species/sizes of low commercial value that they would normally discard if fishing was more successful. On the other hand, high quantities of landings usually reflect the catch of large monospecific concentrations of one of the two most abundant species, anchovy and sardine, and in this case relatively little discarding takes place. Rochet and Trenkel (2005) argue that the complexity of the factors affecting discarding results in non-proportionate quantities of landings and discards. This complexity also seems to be the reason for the limited effectiveness of explaining more of the observed variance in our case. Despite the fact that GAMs explained a relatively low portion of the variance, they seem to be a suitable tool for modelling nonlinearities in discard studies. Information on landed catch and geographical coordinates that could be available from fishers' logbooks could be useful for estimating discarded quantities in certain time periods and areas based on the specific or similar GAM analyses.

Spatial differences between the two study areas include a) a lower discard rate in the Ionian Sea; b) a larger number of totally discarded and occasionally marketable species in the Aegean Sea; c) a high representation of mackerel in the Aegean Sea and of picarel in the Ionian Sea landings; and d) different discarding practices in the Ionian Sea, where species (especially round sardinella, bogue and picarel) are either almost totally retained or totally discarded, while in the Aegean Sea, there are usually intermediate discarding practices. The latter has also been described for the Ionian Sea artisanal fisheries and was attributed to the fluctuations in market demands (Tzanatos et al. 2007). Although discard rates were very low in both areas, the aforementioned differences can be attributed to the different relative biomass of the species in the communities and to different fishing and discarding strategies. The higher number of species in the Aegean Sea is probably due to the higher sampling effort as well as to the fact that the sampled area was larger in the Aegean Sea, resulting in more diverse communities compared to the Ionian sampling. Moreover, in the Aegean Sea the seabed is characterized by a smoother slope due to the extended continental shelf so that the purse seine net can fish more effectively over the seabed, and consequently catch a higher number of demersal species in relation to in the Ionian Sea.

The night purse seine fishery in Greece targets almost exclusively small pelagic fish, which are attracted by light lamps, and as a result it is characterized by high selectivity in terms of species composition. The implementation of legal measures and stricter inspection by the authorities may result in an increase in the discarded quantities, and/or may lead fishers to adapt their strategies, e.g. by targeting aggregations of larger fish. Technical measures, such as an increase in mesh size of the upper part of the seine may increase the size selectivity of the gear. However, discarding practices are influenced by fishing processes and fishers' decision making, which, at least in Greece, is affected by several factors, such as weather conditions, economic pressure, market demands, alternative fishing strategies, previously gathered information and personal skills (Tsitsika and Maravelias 2006). In any case, taking into account the particularities of the Greek fisheries (e.g. numerous landing sites, which are very difficult to supervise), establishing the closed fishing period and/or areas more efficiently might be a more effective management tool to avoid juvenile catches, and taking into account recruitment periods and nursery grounds for target species should be considered. Policies aiming to reduce discards and/or further utilize them, should be a result of careful analysis (Bellido et al. 2011), without disregarding cultural characteristics (Johnsen and Eliasen 2011) and possible positive effects on food-web components, including charismatic species such as seabirds (Arcos and Oro 2002), always in terms of EBM of fishery resources.

\section{ACKNOWLEDGEMENTS}

We thank S. Kavadas for his valuable help concerning data handling. The editor Dr. P. Martin and three anonymous referees greatly helped in improving the manuscript.

\section{REFERENCES}

Adamidou A., 2007. Commercial fishing gears and methods used in Hellas. In: Papaconstantinou C., Zenetos A., Vassilopoulou V., Tserpes G. (eds), State of Hellenic fisheries. HCMR Publ., pp. 118-131.

Anon. 2008. National Program for the Collection of Fisheries Data (2007-2008). Technical Report (EC 1543/2000). Fisheries Research Institute and Hellenic Center for Marine Research, Athens, Greece, 341 pp.

Antonakakis K., Giannoulaki M., Machias A., Somarakis S., Sanchez S., Ibaibarriaga L., Uriarte A. 2011. Assessment of the sardine (Sardina pilchardus Walbaum, 1792) fishery in the eastern Mediterranean basin (North Aegean Sea). Medit. Mar. Sci. 12: 333-357.

Arcos J.M., Oro D. 2002. Significance of nocturnal purse seine fisheries for seabirds: a case study off the Ebro Delta (NW Mediterranean). Mar. Biol. 141: 277-286.

Bariche M., Alwan N., El-Fadel M. 2006. Structure and biological characteristics of purse seine landings off the Lebanese coast (eastern Mediterranean). Fish. Res. 82: 246-252.

Bellido J., Santos M., Pennino M., Valeiras X., Pierce G. 2011. Fishery discards and bycatch: solutions for an ecosystem approach to fisheries management? Hydrobiologia 670: 317-333.

Borges L., Zuur A.F., Rogan E., Officer R. 2005. Choosing the best sampling unit and auxiliary variable for discards estimations. Fish. Res. 75: 29-39.

Borges T.C., Erzini K., Bentes L., Costa M.E., Goncalves J.M.S., Lino P.G., Pais C., Ribeiro J. 2001. By-catch and discarding practices in five Algarve (southern Portugal) metiers. J. Appl. Icthyol. 17: 104-114.

Burnham K.P., Anderson D.R. 2002. Model selection and Multimodel Inference: A Practical Information-Theoretic Approach. Springer, New York, $485 \mathrm{pp}$.

Cetinić P., Śkeljo F., Ferri J. 2011. Discards of the commercial boat seine fisheries on Posidonia oceanica beds in the eastern Adriatic Sea. Sci. Mar. 75(2): 289-300. 
Cochran W.G. 1977. Sampling techniques. Wiley and sons, NY, 428 pp. Depestele J., Vandemaele S., Vanhee W., Polet H., Torreele E., Leirs H., Vincx M. 2011. Quantifying causes of discard variability: an indispensable assistance to discard estimation and a paramount need for policy measures. ICES J. Mar. Sci. 68: $1719-1725$.

El.Stat. 2011. Quantity of fish landed by fishing area and fishing tools. Hellenic Statistical Authority, http://www.statistics.gr.

EU 2008. Directive 2008/56/EC of the European Parliament and of the council. Establishing a framework for community action in the field of marine environmental policy (Marine Strategy Framework Directive). Official Journal of the European Union.

EU 2009. Green paper. Reform of the Common Fisheries Policy. Commission of the European Communities.

FAO. 2010. Report of the technical consultation to develop international guidelines on bycatch management and reduction of discards. Rome. no 957, 32 pp.

Garcia S.M., Zerbi A., Aliaume C., Do Chi T., Lasserre G. 2003. The ecosystem approach to fisheries. Issues, terminology, principles, institutional foundations, implementation and outlook. FAO Fisheries Technical Paper No. 443. FAO, p. 71

Gezelius S.S. 2008. Management responses to the problem of incidental catch in fishing: A comparative analysis of the EU, Norway, and the Faeroe Islands. Mar. Policy 32: 360-368.

Hastie T., Tibshirani R. 1990. Generalized Additive Models. Chapman \& Hall, London, $335 \mathrm{pp}$.

Hilborn R. 2011. Future directions in ecosystem based fisheries management: A personal perspective. Fish. Res. 108: 235-239.

Huse I., Vold A. 2010. Mortality of mackerel (Scomber scombrus L.) after pursing and slipping from a purse seine. Fish. Res. 106: 54-59.

Jennings S., Kaiser M.J. 1998. The effects of fishing on marine ecosystems. Adv. Mar. Biol. 34: 201-352.

Johnsen J.P., Eliasen S. 2011. Solving complex fisheries management problems: What the EU can learn from the Nordic experiences of reduction of discards. Mar. Policy 35: 130-139.

Kapantagakis A., 2007. Management and legislation In Hellenic fisheries. In: Papaconstantinou C., Zenetos A., Vassilopoulou V., Tserpes G. (eds.), State of Hellenic fisheries. HCMR Publ., pp. $151-158$

Kelleher K. 2005. Discards in the world's marine fisheries. An update. Rome. No. 470, $131 \mathrm{pp}$.

Lleonart J., Maynou F. 2003. Fish stock assessments in the Mediterranean: state of the art. Sci. Mar. 67(Suppl. 1): 37-49.

Machias A., Vasilopoulou V., Vatsos D., Bekas P., Kallianotis A., Papaconstantinou C., Tsimenides N. 2001. Bottom trawl discards in the northeastern Mediterranean Sea. Fish. Res. 53: 181-195.

Machias A., Maiorano P., Vasilopoulou V., Papaconstantinou C., Tursi A., Tsimenides N. 2004. Sizes of discarded commercial species in the eastern-central Mediterranean Sea. Fish. Res. 66: 213-222.

Marcalo A., Marques T.A., Araujo J., Pousao-Ferreira P., Erzini K., Stratoudakis Y. 2010. Fishing simulation experiments for predicting the effects of purse-seine capture on sardine (Sardina pilchardus). ICES J. Mar. Sci. 67: 334-344.

Mitchell R.W., Blight S.J., Gaughan D.J., Wright I.W. 2002. Does the mortality of released Sardinops sagax increase if rolled over the headline of a purse seine net? Fish. Res. 57: 279-285.

Petrakis G., Stergiou K.I. 1997. Size selectivity of diamond and square mesh codends for four commercial Mediterranean fish species. ICES J. Mar. Sci. 54: 13-23.

R Development Core Team 2010. R: A Language and Environment for Statistical Computing. R Foundation for Statistical Computing. http://www.Rproject.org.

Rochet M.J., Trenkel V.M. 2005. Factors for the variability of discards: assumptions and field evidence. Can. J. Fish. Aquat. Sci. 62: $224-235$.
Rochet M.J., Collie J.S., Jennings S., Hall S.J. 2011. Does selective fishing conserve community biodiversity? Predictions from a length-based multispecies model. Can. J. Fish. Aquat. Sci. 68: 469-486.

Şahin C., Hacımurtezaoğlu N., Gözler A.M., Kalaycı F., Ağırbaş E. 2008. A Prelimenary Study on Investigation of Purse Seine Bycatch Composition in the Southeastern Black Sea. J. Fish. Sci. 2: 677-683.

Santojanni A., Cingolani N., Arneri E., Kirkwood G., Belardinelli A., Giannetti G., Colella S., Donato F., Barry C. 2005. Stock assessment of sardine (Sardina pilchardus, Walb.) in the Adriatic Sea with an estimate of discards. Sci. Mar. 69: 603-617.

SGMED (Study Froup on the Mediterranean), 2009. Stock assessment of anchovy in GSA 22. In: Cardinale M., Cheilari A., Ratz H.J. (eds.), Scientific, Technical and Economic Committee for Fisheries (STECF), Report of the SGMED-09-02 Working Group on the Mediterranean - Part I. European Commission. Italy, pp. 583-603. Available from http://publications.jrc. ec.europa.eu/repository/handle/111111111/8490

Somarakis S., Tsianis D.E., Machias A., Stergiou K.I. 2006. An overview of biological data related to anchovy and sardine stocks in Greek waters. In: Palomares M.L.D., Stergiou K.I., Pauly D. (eds.), Fishes in Databases and Ecosystems, Fisheries Centre Research Reports 14(4). Fisheries Centre, University of British Columbia, pp. 56-64.

STECF (Scientific, Technical and Economic Committee for Fisheries) 2009. M. Cardinale, A. Cheilari, H.J. Ratz (Editors), Report of the SGMED-09-02 Working Group on the Mediterranean - Part I. European Commission. Italy, 846 pp. Available from http://publications.jrc.ec.europa.eu/repository/ handle/111111111/8490

Stergiou K.I., Christou E.D., Georgopoulos D., Zenetos A., Souvermesoglou C. 1997. Hellenic Seas: physics, chemistry, biology and fisheries. Oceanogr. Mar. Biol. Annu. Rev. 35: 415-538.

Stergiou K.I., Moutopoulos D.K., Armenis G. 2009. Perish legally and ecologically: the ineffectiveness of the minimum landing sizes in the Mediterranean Sea. Fish. Manage. Ecol. 16: 368-375.

Stratoudakis Y., Marcalo A. 2002. Sardine slipping during purseseining off northern Portugal. ICES J. Mar. Sci. 59: 1256-1262.

Tsagarakis K., Machias A., Giannoulaki M., Somarakis S., Karakassis I. 2008. Seasonal and temporal trends in metrics of fish community for otter-trawl discards in a Mediterranean ecosystem. ICES J. Mar. Sci. 65: 539-550.

Tsikliras A.C. 2008. Climate-related geographic shift and sudden population increase of a small pelagic fish (Sardinella aurita) in the eastern Mediterranean Sea. Mar. Biol. Res. 4: 477-481

Tsitsika E.V., Maravelias C.D. 2006. Factors affecting purse seine catches: an observer-based analysis. Medit. Mar. Sci. 7: 27-40.

Tzanatos E., Somarakis S., Tserpes G., Koutsikopoulos C. 2007. Discarding practices in a Mediterranean small-scale fishing fleet (Patraikos Gulf, Greece). Fish. Manage. Ecol. 14: 277-285.

Vidoris P., Argyrokastritis A., Kallianiotis A. 2001. Purse seine catches composition in Kavala fishing port. Proceedings of the Working Group on Small Pelagic species, Sub-committee for Stock assessment, Scientific Advisory Committee, General Fisheries Commission for the Mediterranean, Kavala, 27-30 March.

Voulgaridou P., Stergiou I.K. 2003. Trends in various biological parameters of the European sardine, Sardina pilchardus (Walbaum, 1792), in the Eastern Mediterranean Sea. Sci. Mar. 67(Suppl. 1): 269-280.

Wood S.N. 2006. Generalized Additive Models. An Introduction with $R$. Chapman \& Hall, London, $391 \mathrm{pp}$.

Scient. ed.: P. Martín.

Received June 23, 2011. Accepted March 7, 2012.

Published online August 2, 2012. 